\title{
Response of Onion to Different Organic Amendments in Central Uganda
}

\author{
Bosco Bua, Raphael Owiny and Akasairi Ocwa \\ Department of Agriculture, Kyambogo University, P.O. Box 1, Kyambogo-Kampala, Uganda
}

\begin{abstract}
Onion is one of the most important vegetable crops grown in Uganda, because of its nutritional and economic value. However, production of onion in Uganda is very low due to nutritional imbalances in the soil. Therefore, soil fertility remains one of the key areas of focus in sustaining onion production. A field experiment was conducted to assess the response of onion variety Red Creole C-5 to different soil organic amendments at Kyambogo University during the period February 2016 and January 2017. The experiment was laid out in a randomized complete block design with four replications. The treatments included $\mathrm{T}_{0}$ : without manure (control), $\mathrm{T}_{1}$ : green manure (GM), $\mathrm{T}_{2}$ : farmyard manure (FYM) and $\mathrm{T}_{3}$ : compost manure (CM). Data collected included: plant height, root length, plant fresh and dry weight, number of leaves per plant, fresh and dry weight of bulbs, diameter of bulbs and commercial yield computed. Data were analysed using Genstat. There was significant response of onion to the different soil organic amendments. Onion plant height, number of leaves, root length, dry and fresh weight and bulb weight were high in farmyard manure, followed by compost manure and lastly green manure, compared to the control. The highest yield $(12,000 \mathrm{~kg} / \mathrm{ha}) \mathrm{was}$ obtained from the plots amended with farmyard manure as opposed to the control. It was therefore concluded that farmyard manures had a greater effect on the agronomic and yield performance of onion. Future study with more than one onion genotype is recommended so as to widen the scope of this result.
\end{abstract}

Key words: Onion, organic manures, growth, yield.

\section{Introduction}

Onion (Allium cepa L.) is one of the most important commercial vegetable crops grown intensively in the world. Onion is produced on 2.96 million ha with an annual production of 60 million metric tons from over 134 different countries with Uganda ranked the 47th in terms of global production accounting for $0.2 \%$ [1]. Onion has significant contribution in human diet, economic earnings as well as valued for their medicinal properties [2]. Onion is consumed primarily for unique flavor or ability to enhance flavor in food $[3,4]$. The common varieties of onions grown in Uganda include Jamba, Red Creole, Red cornet, Bombay, Afri seed, Pearl, Red passion and Texas Grano [5].

In Uganda, onion is majorly grown in Kigezi, Rakai,

Corresponding author: Bosco Bua, associate professor, research fields: crop science, plant diseases diagnosis, management and epidemiology, pathogens genetic diversity, horticulture.
Mbarara, Mbale and Tororo. The total area covered by onion crop is 37,000 ha, with total production of 147,000 tons and average productivity of 4.02 tons/ha [6]. This is very low yield compared to the world average of 19.7 tons/ha [7]. Low yield is attributed to factors, such as low soil fertility, pests, diseases, price fluctuation and poor storage facilities among others [5, 8]. Moreover, lack of improved varieties and seed, and absence of recommended organic fertilizer rates are the pertinent problems in any given area [2].

Therefore, to improve onion production, a number of inputs are required, including adequate soil fertility management [4]. In the developing countries, the escalating price of inorganic fertilizers is a hindrance to the small and marginal farmers [9]. Accordingly, integrated nutrient management, especially the use of different soil organic amendments, has gained tremendous importance in many countries [10]. In fact, soil organic amendments remain the only feasible option for the small holder farmers, because it is cheap, 
affordable and capable of improving the physical, chemical and biological properties of the soil [11, 12]. Besides, organic materials, such as farmyard manure, not only improve soil physical and chemical properties but also have positive effect on root growth, such as improving the root rhizosphere conditions (structure, humidity), as well as encouraging increasing population of microorganisms [13, 14]. Also, organic fertilizers support and sustain healthy ecosystems, food production and overall economy in terms of human health [12]. However, the information on the response of onion to different organic amendments in central Uganda is scanty and limited. Therefore, the objective of this study was to assess the response of the onion variety Red Creole C-5 to the different organic amendments in central Uganda.

\section{Materials and Methods}

\subsection{Study Area}

The study was conducted at Kyambogo University located $8 \mathrm{~km}$ from Kampala city along Kampala-Jinja highway. Kyambogo is $1,189 \mathrm{~m}$ above sea level, $00^{\circ} 20^{\prime} 54^{\prime \prime} \mathrm{N}$ and $32^{\circ} 37^{\prime} 49^{\prime \prime} \mathrm{E}$. The mean annual rainfall ranged between $1,000 \mathrm{~mm}$ and $1,200 \mathrm{~mm}$. The minimum and maximum temperatures were $28^{\circ} \mathrm{C}$ and $30^{\circ} \mathrm{C}$, respectively [15, 16]. The predominant soil at the experimental field was loamy sand soils (Table 1).

\subsection{Raising of Seedlings}

First, the seedlings of onion variety Red Creole C-5 were raised in a nursery bed for eight weeks before transplanting. Prior to transplanting, hardening off was done by reducing the frequency of watering and gradual reduction of shade [5].

\subsection{Experiment Block}

The experiment was laid out in a randomized complete block design with four replications. Each block measured $1 \mathrm{~m} \times 5 \mathrm{~m}$ and experimental unit of 1 $\mathrm{m} \times 1 \mathrm{~m}$. Each block had four experimental units. Onions were planted at the spacing of $30 \mathrm{~cm}$ between rows and $15 \mathrm{~cm}$ between plants.

\subsection{Organic Amendments Preparation and Application}

Farmyard, compost manure and green manure were prepared as described by Chandra [17]. Compost and farmyard manures were applied to the plots during the time of transplanting at a single rate of 2 tons/ha using drill method. Green manure was sown at the rate of 6 $\mathrm{kg} / \mathrm{ha}$ and was prepared by incorporating flowering cowpea plants into the ground and allowed to decompose for four weeks before planting. The chemical compositions of all the organic amendments are presented in Table 2 .

\subsection{Management Practices}

Weeding was done as necessary by hoeing and hand removal. Earthing up was done to prevent exposure of bulbs. No inorganic fertilizer and pesticides were applied to the field throughout the life of the plant. Irrigation was done as necessary to avoid water stress.

Table 1 Physico-chemical properties of soil at the experimental site.

\begin{tabular}{llllll}
\hline Organic matter (\%) & Nitrogen (\%) & Phosphorus (\%) & Potassium (\%) & Soil texture & Soil $\mathrm{pH}$ \\
\hline 4.2 & 0.98 & 0.01 & 0.33 & Loamy sand & 6.8 \\
\hline
\end{tabular}

Table 2 Chemical composition of organic amendments.

\begin{tabular}{llll}
\hline \multirow{2}{*}{ Organic manure } & \multicolumn{3}{c}{ Percentage of major elements (\%) } \\
\cline { 2 - 4 } & Nitrogen & Phosphorous & Potassium \\
\hline Farmyard manure & 3.60 & 0.72 & 1.94 \\
Compost manure & 2.82 & 0.45 & 1.33 \\
Green manure & 2.14 & 0.22 & 0.82 \\
\hline
\end{tabular}


Harvesting was done by digging out the bulbs using the hand hoe at 90 days after transplanting (DAT).

\subsection{Data Collection and Analysis}

Data collection commenced on 14 DAT, and continued on a two weekly intervals until harvesting. The data collected included: plant height, number of leaves per plant, plant fresh and dry weight, bulb fresh and dry weight, bulb diameter and commercial yield. Four onion plants per treatment were randomly sampled. Their heights were measured using a meter ruler from apex to bottom; number of leaves were manually counted and averaged; fresh and dry weight were measured using electronic balance and yield per hectare ( $\mathrm{kg} / \mathrm{ha})$ computed [14].

Soil data (organic matter content, nitrogen, potassium and phosphorus content) and agronomic data were subjected to the analysis of variance (ANOVA) of the Genstat computer software. Initially, data for each season were analyzed separately. However, since there was no significant season effect, pooled data were analyzed to test seasonal effects. Means were separated using least significance difference (LSD) test at 5\% probability level.

\section{Results}

Onion height, number of leaves, length of roots, bulb fresh and dry weight, bulb diameter, and yield were significantly $(P<0.05)$ affected by organic amendments. However, the interaction of onion genotype and organic amendments did not significantly $(P>0.05)$ influence the growth and yield of onion. Also season had no effect on growth parameters, yield and yield components of onion.

At 14 DAT, the highest number of leaves (7.2) was recorded in farmyard manure and the lowest (5.2) in green manure treated plots, compared to the control (without manure) (4.2). Similarly, the highest and the lowest plant height were recorded in farmyard manure and green manure treated plots, respectively, compared to the control. A similar trend was followed by root length (Table 3 ).

Similarly, at 28 DAT, the highest number of leaves (8.95) was recorded in farmyard manure and the lowest (7.71) in green manure, compared to the control (5.76), while the highest and the lowest plant height were recorded from farmyard manure $(37.89 \mathrm{~cm})$ and green manure $(25.2 \mathrm{~cm})$ treated plots, compared to the control $(23.61 \mathrm{~cm})$. The highest root length was obtained in farmyard manure $(11.1 \mathrm{~cm})$ and the lowest $(8.95 \mathrm{~cm})$ in green manure, compared to the control $(7.38 \mathrm{~cm})$ (Table 4). Overall, a similar trend was observed at 42, 56 and 70 DAT (Tables 5-7).

Fresh weight, dry weight of onion plants and yield was recorded at 90 DAT. Accordingly, the highest and lowest plant fresh and dry weight were recorded in farmyard manure and green manure, respectively, compared to the control (Fig. 1). The highest bulb diameter $(6.7 \mathrm{~cm})$ was obtained in farmyard manure and the lowest $(4.2 \mathrm{~cm})$ in green manure, although this did not differ significantly $(P>0.05)$ from the control $(4.2 \mathrm{~cm})$ (Fig. 2). Additionally, the highest and the lowest commercial yield was recorded in farmyard manure (12,000 kg/ha) and green manure (7,200 kg/ha),

Table 3 Mean number of leaves, plant height and root length of onions amended with different soil organic amendments at 14 DAT in Kyambogo University farm, 2016.

\begin{tabular}{llll}
\hline Treatment & Number of leaves & Plant height $(\mathrm{cm})$ & Root length $(\mathrm{cm})$ \\
\hline Farmyard manure & 7.21 & 20.76 & 10.00 \\
Green manure & 5.22 & 14.95 & 7.45 \\
Compost manure & 6.44 & 16.42 & 8.30 \\
Control & 4.23 & 12.64 & 6.20 \\
\hline Mean & 5.78 & 16.12 & 7.99 \\
LSD $_{(5 \%)}$ & 0.86 & 0.81 & 0.84 \\
\hline
\end{tabular}


Table 4 Mean number of leaves, plant height and root length of onions amended with different soil organic amendments at 28 DAT in Kyambogo University farm, 2016.

\begin{tabular}{llll}
\hline Treatment & Number of leaves & Plant height $(\mathrm{cm})$ & Root length $(\mathrm{cm})$ \\
\hline Farmyard manure & 8.95 & 37.89 & 11.12 \\
Green manure & 7.71 & 25.22 & 8.95 \\
Compost manure & 8.42 & 32.21 & 9.43 \\
Control & 5.76 & 23.61 & 7.38 \\
\hline Mean & 7.71 & 29.73 & 9.22 \\
LSD $_{(5 \%)}$ & 0.50 & 2.63 & 0.84 \\
\hline
\end{tabular}

Table 5 Mean number of leaves, plant height and root length of onions amended with different soil organic amendments at 42 DAT in Kyambogo University farm, 2016.

\begin{tabular}{llll}
\hline Treatment & Number of leaves & Plant height $(\mathrm{cm})$ & Root length $(\mathrm{cm})$ \\
\hline Farmyard manure & 10.96 & 57.35 & 14.53 \\
Green manure & 8.72 & 47.37 & 9.88 \\
Compost manure & 9.66 & 50.28 & 11.90 \\
Control & 7.00 & 45.37 & 8.45 \\
\hline Mean & 9.09 & 50.09 & 11.19 \\
LSD $_{(5 \%)}$ & 0.45 & 2.67 & 1.16 \\
\hline
\end{tabular}

Table 6 Mean number of leaves, plant height and root length of onions amended with different soil organic amendments at 56 DAT in Kyambogo University farm, 2016.

\begin{tabular}{llll}
\hline Treatment & Number of leaves & Plant height $(\mathrm{cm})$ & Root length $(\mathrm{cm})$ \\
\hline Farmyard manure & 12.00 & 64.33 & 15.00 \\
Green manure & 10.00 & 58.47 & 14.10 \\
Compost manure & 11.00 & 62.82 & 13.12 \\
Control & 9.00 & 54.62 & 11.72 \\
\hline Mean & 10.50 & 60.06 & 13.49 \\
LSD $_{(5 \%)}$ & 2.62 & 1.92 & 1.58 \\
\hline
\end{tabular}

Table 7 Mean number of leaves, plant height and root length of onions amended with different soil organic amendments at 70 DAT in Kyambogo University farm, 2016.

\begin{tabular}{llll}
\hline Treatment & Number of leaves & Plant height $(\mathrm{cm})$ & Root length $(\mathrm{cm})$ \\
\hline Farmyard manure & 6.21 & 69.32 & 5.50 \\
Green manure & 4.32 & 62.54 & 7.07 \\
Compost manure & 5.10 & 69.98 & 6.25 \\
Control & 3.57 & 57.32 & 7.45 \\
\hline Mean & 7.68 & 64.79 & 6.57 \\
LSD $_{(5 \%)}$ & 1.10 & 1.59 & 1.55 \\
\hline
\end{tabular}

respectively, compared to the control $(5,800 \mathrm{~kg} / \mathrm{ha})$ (Fig. 3).

\section{Discussion}

Growth parameters were significantly influenced by the different treatments. For example, the highest number of leaves, the tallest plants and the longest roots at all stages of growth were recorded in the plots where farmyard manure was applied as opposed to the other treatments. This was attributed to the high percentage of nitrogen and phosphorus that promote vegetative growth and root development. The high nitrogen content in farmyard manure promoted cell division, resulting into rapid growth of the shoot system and elongation of the onion roots. Additionally, high nitrogen and phosphorus contents could have facilitated utilization of other essential elements in the soil. This finding compares well with 


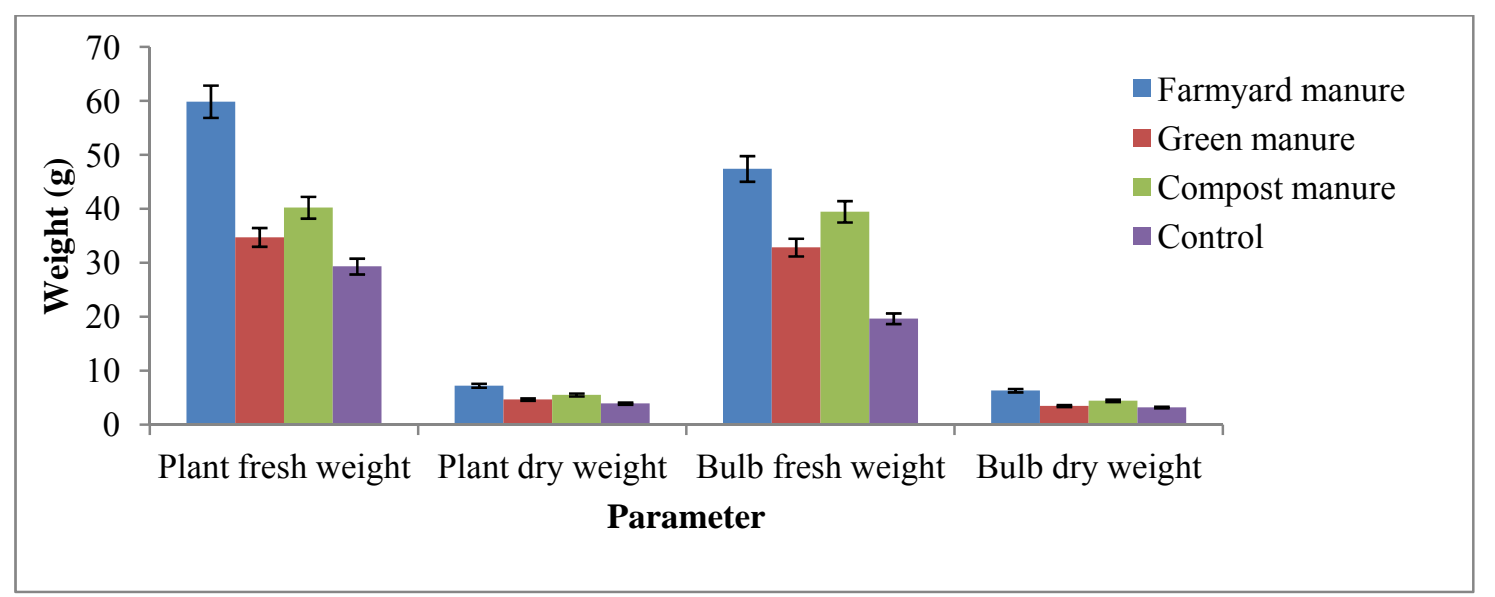

Fig. 1 Fresh and dry weight, bulb fresh and dry weight of onion plant at 90 DAT at Kyambogo University, 2016.

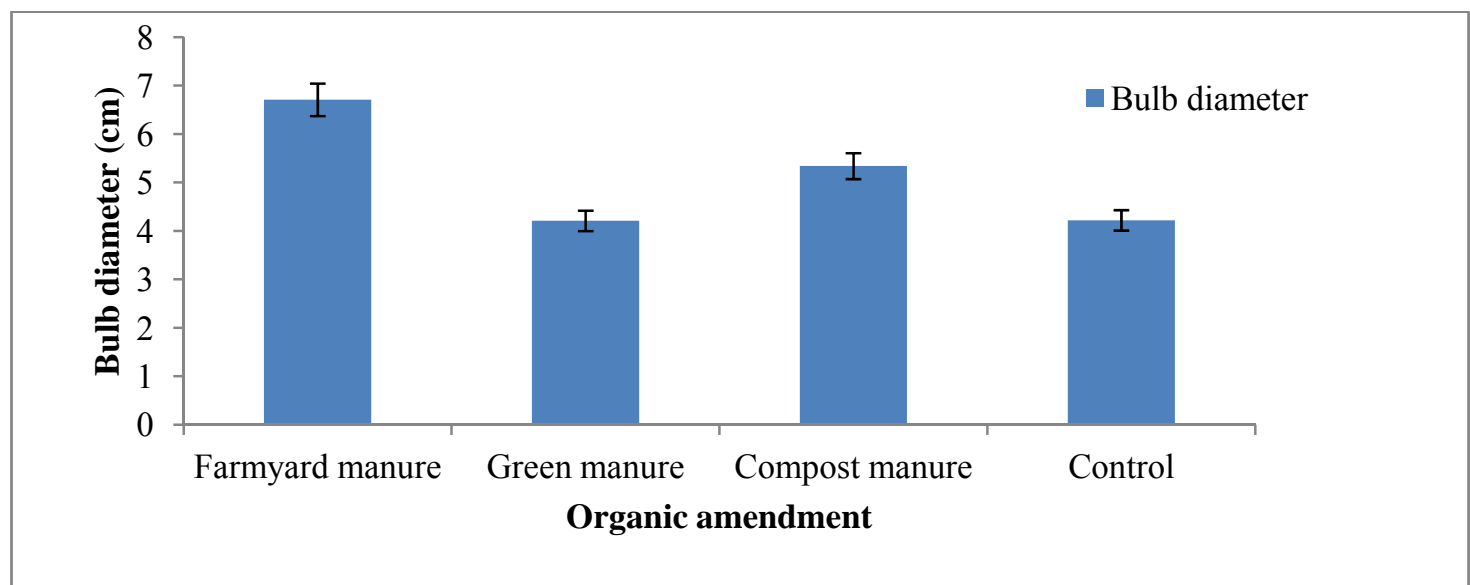

Fig. 2 Onion bulb diameter at 90 DAT at Kyambogo University, 2016.

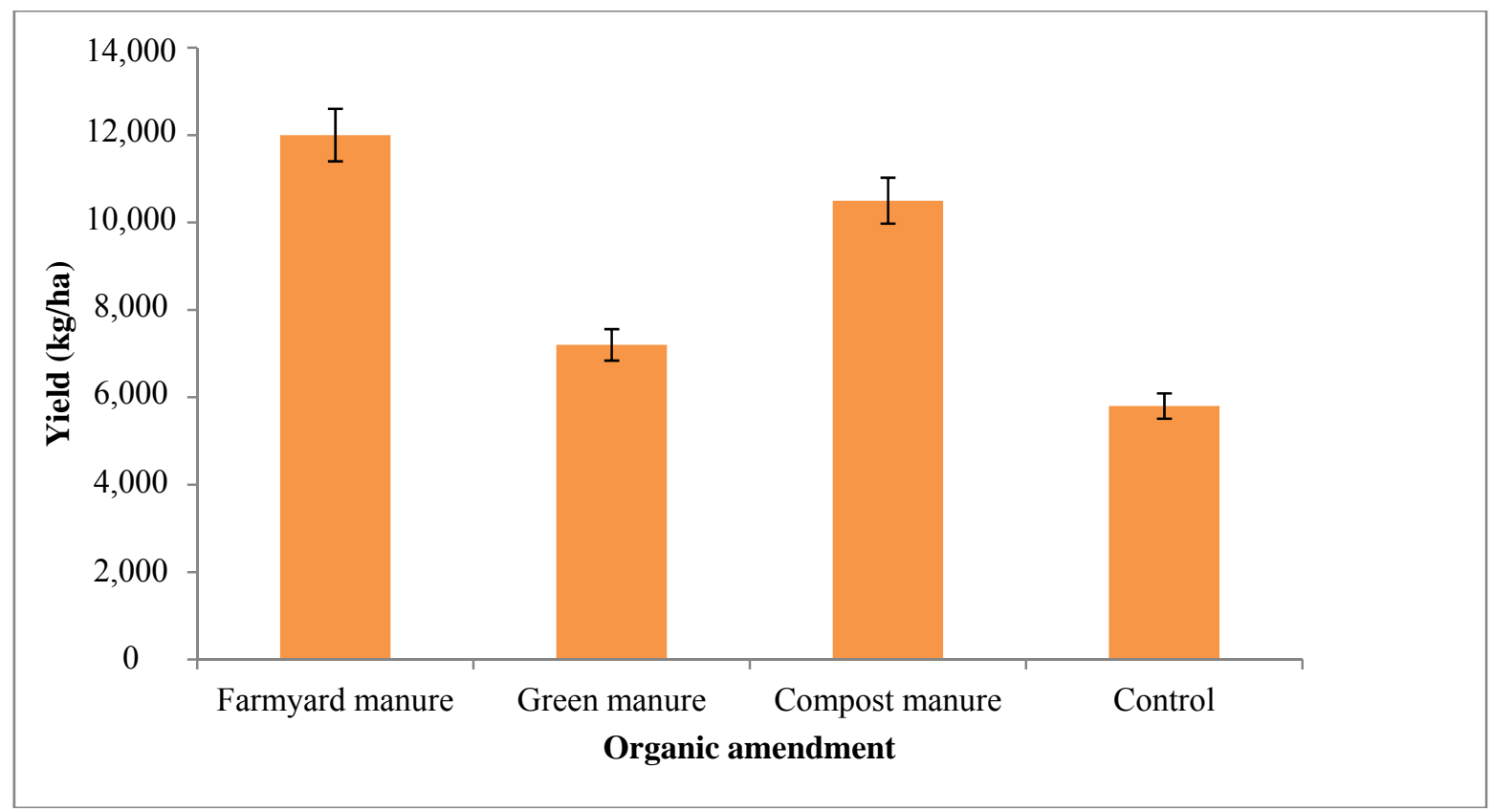

Fig. 3 Yield of onion at 90 DAT at Kyambogo University, 2016. 
those of Yasser and Khalid [18], who reported that organic amendments, especially animal manure, improve vegetative growth characters of onions. In fact, it had earlier been demonstrated that application of farmyard manure significantly improved the growth and yields of onions [19, 20]. Similarly, El-shatanofy [21] indicated that application of organic manure resulted into higher fresh and dry weight of onion plants. The longer root length in farmyard manure was attributed to improved soil texture and higher phosphorus percentage which facilitated root penetration, growth and elongation. This finding therefore compares very well with those of Dauda et al. [22] and Gambo et al. [23], respectively. Accordingly, addition of organic amendments improves soil structure, which can encourage root growth and development [11].

Fresh and dry weight, bulb diameter and commercial yield of onions were also higher in plots amended with different organic amendments in comparison with the control. Higher nitrogen content in farmyard manure promoted succulence of onion leaves, resulting into higher fresh weight. Also more vegetative growth in farmyard manure resulted into higher interception of photosynthetically active radiation (PAR), hence accumulation of assimilates in the sink (bulb) resulting into higher yield. This compares very well with Yasser and Khalid [18], who reported that nitrogen facilitated rapid leaf growth, and hence improved surface area for interception of PAR. Additionally, Coolong et al. [24] stated that in onion bulbs, nitrogen and phosphorus contents were increased by nitrogen application. Besides, considerable quantity of phosphorus in farmyard manure resulted into rapid root growth, which improved nutrient absorption resulting into high yield.

Organic manures activate many species of living organisms which release phytohormones that may stimulate the plant growth and absorption of nutrients, and such organisms need nitrogen for multiplication $[1,25]$. This results in the increased onion yield [26].
Similarly, Singh et al. [27] reported that application of organic manures resulted into higher bulb yield in comparison with their unfertilized counterpart. Also, Mandloi et al. [9] reported higher yield in farmyard manure, compared to other organic amendments. In general, the onion yields obtained from all treatments per ha were lower, compared to average of 19,700 $\mathrm{kg} / \mathrm{ha}[7]$.

\section{Conclusions and Recommendation}

Organic amendments had positive effect on the growth and yield of onion. However, there is need to encourage the farming community to adopt the usage of organic amendments in onion production as opposed to the inorganic fertilizers which is not only expensive but also has a long term effects on the environment.

\section{Acknowledgments}

This work is an output by the second author in partial fulfillment of the requirements for the award of the Bachelor of Vocational Studies in Agriculture with Education of Kyambogo University.

\section{References}

[1] FAO. 2013. Food and Agricultural Organization Statistical Database.

[2] Gessesew, W. S., Woldetsadik, K., and Wassu, M. 2015. "Growth Parameters of Onion (Allium cepa L. var. Cepa) as Affected by Nitrogen Fertilizer Rates and Intra-row Spacing under Irrigation in Gode, South-Eastern Ethiopia." Agriculture, Forestry and Fisheries 4 (6): 239-45.

[3] Raddle, M. W. 2000. "Increasing Nitrogen Concentration in Hydroponic Solutions Effects on Onion Flavor and Bulb Quality.” J. Am. Soc. Hort. Sci. 125 (2): 254-9.

[4] Yohannes, K. W., Belew, D., and Debela, A. 2013. "Effect of Farmyard Manure and Nitrogen Application Rates on Growth, Yield and Yield Components of Onion." Asian J. Plant Sci. 12 (6-8): 228-34.

[5] Musokya, D. 2012. "Getting the Best from Your Jambar F1.” Seed Time News Letters. Accesssed December, 2012. http://www.monsantoafrica.com/_pdfs/newsletters/seed_t ime_2012_oct_dec.pdf.

[6] Sonko, R., Njue, E., Ssebuliba, J. M., and Jager, A. 2005. 
Pro-poor Horticulture in East Africa and South-East Asia: Horticultural Sector in Uganda. Leuven: International Society for Horticultural Science (ISHS).

[7] Haq, M. T., Akter, M., and Haque, M. M. 2016. "Performance of Summer Onions at Kotalipara, Gopalgonj." Eco-friendly Agril. J. 9 (6): 27-8.

[8] Zziwa, Z., and Kabirizi, J. 2015. "Constraints to Integration of Vegetable Production in Smallholder Dairy Systems of Uganda." Int. J. Res. Stud. Biosci. 3 (1): 141-9.

[9] Mandloi, K. S., Boss, U. S., and Deshmukh, K. S. 2008. "Effect of Organic Manures and Inorganic Fertilizers on Growth and Yield of Onion (Allium cepa L.)." The Asian Journal of Horticulture 3 (2): 238-40.

[10] Mohd, R., Narwadkar, P. R., Prabu, T., and Sajindranath, A. K. 2002. "Effect of Organic and Inorganic Fertilizers on Yield and Quality of Tomato (Lycopersicon esculentum Mill.)." J. Soils and Crops 12 (2): 167-9.

[11] Ahmed, K. A., Sharief, A. E., and Fathalla, H. F. 2013. "Effect of Organic and Mineral Fertilizers on Vegetative Growth, Bulb Yield and Quality of Onion Cultivars." Crop Prod. 2 (3): 91-100.

[12] Islam, A., Islam, S., Ayasha, A., Rahman, H., and Nandwani, D. 2017. Effect of Organic and Inorganic Fertilizers on Soil Properties and the Growth, Yield and Quality of Tomato in Mymensingh, Bangladesh." Agriculture 7 (3): 18.

[13] Shaheen, A., Fatma, M., Rizk, A., and Singer, S. M. 2007. "Growing Onion Plants without Chemical Fertilization." Res. J. Agr. Bio. Sci. 3 (2): 95-104.

[14] Funda, Y., Safak, C., Nilgun, M., and Bihter, C. E. 2011. "Effect of Organic and Inorganic Fertilizers on Yield and Mineral Content of Onion (Allium cepa L.)." African J. Biotechnol. 10 (55): 11488-92.

[15] Kraybill, D., and Kidoido, M. 2009. "Analysis of Relative Profitability of Key Ugandan Agricultural Enterprises by Agricultural Production Zone.” Uganda Strategy Support Program (USSP) Brief No. 7, International Food Policy Research Institute (IFPRI). Accessed November, 2009. http://www.ifpri.org/publication/analysis-relative-profitab ility-key-ugandan-agricultural-enterprises-agricultural.

[16] Bua, B., and Opio, M. 2014. "Variability in Reactions of Groundnuts Varieties to Groundnut Rosette Virus Isolates from Uganda.” Am. J. Exp. Agric. 4 (5): 541-9.
[17] Chandra, K. 2005. Organic Manures. Hebbal, Banglaore: Regional Centre of Organic Farming.

[18] Yassen, A. A., and Khalid, K. A. 2009. "Influence of Organic Fertilizers on the Yield, Essential Oil and Mineral Content of Onion.” Inter. Agrophysics 23 (2): 183-8.

[19] Lal, S., Yadav, A. C., Mangal, J. L., Avatar, S., and Batra, V. K. 2002. "Effects of Farmyard Manure and Irrigation Levels on Growth and Yield of Onion cv. Hisar-2." Haryana J. Hort. Sci. 31 (3-4): 256-8.

[20] Reddy, K. C., and Reddy, K. M. 2005. "Differential Levels of Vermicompost and Nitrogen on Growth and Yield in Onion (Allium cepa L.) and Radish (Raphanus sativus L.) Cropping System.” J. Res. ANGRAU 33 (1): 11-7.

[21] El-shatanofy, M. E. 2011. "Influence of Organic Manure and Inorganic Fertilizers on Growth, Yield and Chemical Contents of Onion (Allium cepa L)." M.Sc. thesis, Alexandria University.

[22] Dauda, S. N., Ajayi, F. A., and Ndor, E. 2008. "Growth and Yield of Watermelon (Citrullus lanatus) as Affected by Poultry Manure Application.” J. Agric. Social Sci. 4 (3): 121-4.

[23] Gambo, B. A., Magaji, M. D., Yakubu, A. I., and Daikon, A. U. 2008. "Effects of Farmyard Manure, Nitrogen and Weed Interference on the Growth and Yield of Onion (Allium cepa L.) at the Sokoto Rima Valley." J. Sustain. Dev. Agric. Environ. 3 (2): 87-92.

[24] Coolong, T. W., Kopsell, D. A., Kopsell, D. E., and Randle, W. M. 2004. "Nitrogen and Sulfur Influence Nutrient Usage and Accumulation in Onion (Alliumcepa L.)." J. Plant Nutr. 27 (9): 1667-86.

[25] Ouda, B. A., and Mahadeen, A. Y. 2008. "Effect of Fertilizers on Growth, Yield, Yield Components, Quality and Certain Nutrient Contents in Broccoli (Brassica oleracea)." Int. J. Agric. Biol. 10 (6): 627-32.

[26] Sharma, R. P., Datt, N., and Sharma, P. K. 2003. "Combined Application of Nitrogen, Phosphorus, Potassium and Farmyard Manure in Onion (Allium cepa) under High Hills, Dry Temperate Conditions of North-Western Himalayas.” Indian J. Agr. Sci. 73 (4): 225-7.

[27] Singh, L., Bhonde, S. R., and Mishra, V. K. 1997. "Effect of Different Organic Manures and Inorganic Fertilizers on Yield and Quality of Rabi Onion." News Let.-Natl. Hort. Res. Dev. Foundation 17 (3): 1-3. 